\title{
鼻副鼻腔内反性乳頭腫の臨床的検討
}

\author{
名古屋大学大学院医学系研究科頭頸部・感覚器外科学講座耳鼻咽喉科学教室 \\ *国立療養所中部病院耳鼻咽喉科 \\ **刈谷総合病院耳鼻咽喉科 \\ 三澤逸人，中田誠一，内田育恵， \\ 古田敏 章**, 中島務
}

\section{A Clinical Study of Inverted Papilloma in the Nasal Cavity and Paranasal Sinuses}

\author{
Hayato Misawa, Seiichi Nakata, Yasue Uchida*, \\ Toshiaki Furuta**, Tsutomu Nakashima \\ Department of Otolaryngology, Graduate School of Medicine, Nagoya University, Nagoya \\ ${ }^{*}$ Department of Otolaryngology, Chubu National Hospital, Obu, Aichi \\ ${ }^{* *}$ Department of Otolaryngology, The Kariya General Hospital, Kariya, Aichi
}

\begin{abstract}
We conducted a retrospective clinical study of inverted papilloma in the nose and paranasal sinuses in 26 cases (28 sides) of inverted papilloma in the last 10 years. The subjects were 17 men and 9 women with a mean age of 54.6 years. Follow-up averaged 11 months to 10.4 years with a mean of 69.4 months (5. 8 years). Surgical excision is generally regarded as the treatment of choice for papilloma, however, the approach and extent of surgery have been much debated. We clarified the relationship between surgical invasion and disease recurrence. Six of 28 sides developed recurrence (21.4\%), none developed malignant transformation, and 2 of 26 cases $(7.7 \%)$ were diagnosed as with bilateral papillomas. In the endoscopic group, 2 of 8 cases $(25.0 \%)$ recurred, compared to 4 of 20 cases $(20.0 \%)$ in the non-endoscopic group. The amount of blood lost was significantly smaller in the endoscopic group. All 8 cases with aggressive endoscopic resection manifested no recurrence and minimum blood loss. We concluded that aggressive endoscopic resection is the best treatment in terms of recurrence rate and surgical invasion. In general, this approach is preferable for tumors in the nasal cavity or in those localized with a clear endoscopic view in the paranasal sinuses.
\end{abstract}

Key words : papilloma, endoscopic sinus surgery, treatment, nasal cavity, paranasal sinus

\section{はじめに}

鼻副鼻腔領域の内反性乳頭腫は再発性, 悪性化, 組織 破壊性" $の 3$ 徵候で特徵づけられるためにその診断・治 療ともに非常に難渋する疾患である。また本疾患に関し ては特に内視鏡の導入以来どのような症例に対して内視 鏡手術を施行するかについて統一見解に達しておら ず”，低侵襲になれば再発率が上がる3)という意見と内
視鏡症例を厳選すれば同等 ${ }^{4.51}$, あるいは内視鏡と顕微鏡 手術の双方を導入すればほとんどの症例に対応でき再発 率は従来の高侵襲手術と同じ(6) という相反する意見があ る。さらに近年マイクロデブリッダーの開発と進歩に伴 い術中出血の多い本疾患に対しても基部の確認と根治的 切除が鉗子と比較して容易となり, 現在までのところそ れら支援機器の導入後の長期成績がまだ明確でないため に治療，特に手術術式に関して明解な EBM (evidence- 
based medicine）の確立が待たれるところである。今回 われわれは過去10年間の内反性乳頭腫を中心に検討を行 い，新たな知見を得たので文献的考察を加えて報告す る。

\section{対象と方法}

対象（表 1 ）は1992年 5 月から2002年 4 月までの過去 10年間に名古屋大学医学部附属病院を受診した鼻副鼻腔 乳頭腫34例のうち, 扁平上皮性 (exophytic papilloma) ${ }^{71}$ の 4 例と追跡不能の 2 例を除外した 26 名, 28例の鼻副鼻 腔内反性乳頭腫（inverted papilloma）（一側性24側, 両
側性 4 側）である。

性別は男性 17 名, 女性 9 名, 全症例の初診時平均年齢 は54. $6 \pm 14.4$ 歳, 術後平均観察期間は69.4 24.8 ケ月（観 察期間11〜125ヶ月）であった。そのような背景を踏ま え，1992年 5 月〜 2002年 4 月の 10 年間に乳頭腫のなかで も病理学的に内反性乳頭腫と診断され手術を受けた26名 （28側）に対象をしぼって, 腫瘍の基部の発生部位, 術 前診断 · 術式と出血量 - 再発の有無と時期 - 両側例 - 墨 性化などを中心に検討した。

\begin{tabular}{|c|c|c|}
\hline & 34側 \\
\hline \multirow{3}{*}{$\begin{array}{c}\text { 鼻副鼻腔乳頭腫 } \\
\text { 内反性 } \\
\text { 扁平上皮性 }\end{array}$} & (inverted papilloma) & 28名（経過観察不十分2名を除外） \\
\hline & (exophytic papilloma) & (統計から除外) \\
\hline & & 1992年5月〜2002年4月の10年間 \\
\hline 初診時平均年齢 & $54.6 \pm 14.4$ 歳 & （28側26名について解析） \\
\hline 男女比 & 17名：9名 & （28側26名について解析） \\
\hline 術後平均観察期間 & $69.4 \pm 34.8$ ケ月 & （28側26名について解析，観察期間11〜125ヶ月） \\
\hline
\end{tabular}

*ただし両側例は年齢・男女比・術後平均観察期間算出時に 1 名として計算した

\begin{tabular}{|c|c|c|c|c|c|c|c|c|c|c|c|}
\hline 责物 & 年娋 & 性别 & 病理铲影 & 再甡 & 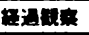 & 彷式(初回) & 菊式(籍2回) & 街式(當3回) & 湔式(策4回) & & \\
\hline 1 & 69 & 5 & 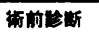 & なし & 39 & Denkeri法 & & & & 上政㜀 & \\
\hline 2 & 59 & S & 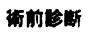 & なし & 60 & AER & & & & 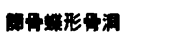 & $\therefore$ \\
\hline 3 & 62 & 女 & 得前籸 & なし & 36 & Denkeri法 & & & & 上酒网 & 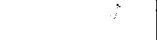 \\
\hline 4 & 82 & 男 & 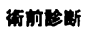 & なし & 42 & AER & & & & 上䮖洞 & \\
\hline 5 & 55 & 男 & 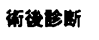 & あり & 26 & FESS & AER+SCFF & & & 上䮖神 & \\
\hline 6 & 33 & n & 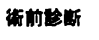 & なし & 13 & AER & & & & 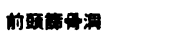 & \\
\hline 7 & 64 & n & 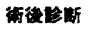 & なし & 11 & FESS & & & & 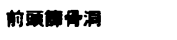 & \\
\hline 8 & 44 & 女 & 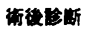 & あり & 15 & FESS & AER & & & D舟爾 & \\
\hline 9 & 31 & 女 & 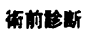 & なし & 61 & C-L法 & & & & 上可明 & \\
\hline 10 & 63 & 用 & 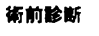 & なし & 74 & FESS & & & & 上政淍 & 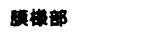 \\
\hline 11 & 51 & 匇 & 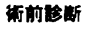 & あり & 70 & EN & FESS & Lat Rhino & & 前战神 & 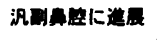 \\
\hline 12 & 53 & 甲 & 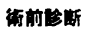 & かし & 125 & Lat Rhino & & & & 中甲介 & 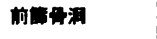 \\
\hline 13 & 75 & 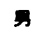 & 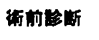 & なし & 63 & Lat Rhino & & & & 中甲介 & 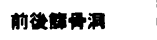 \\
\hline 14 & 35 & 男 & 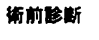 & なし & 107 & Denker+Killian法 & & & & 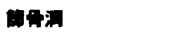 & \\
\hline 15 & 43 & 助 & 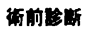 & なし & 77 & Denker法 & & & & 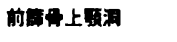 & \\
\hline 16 & 70 & 女 & 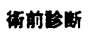 & なし & 118 & Denkeri法 & & & & 上职调 & \\
\hline 17 & 47 & 女 & 街前期断 & なし & 106 & Denker+Killian法 & & & & 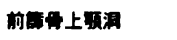 & 塑而管 \\
\hline 18 & 22 & 女 & 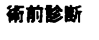 & あり & 96 & Denker+Killian法 & Denkeri法 & & & 厷巷 & 羊細不明 \\
\hline 19 & 60 & 用 & 需前苍断 & なし & 99 & Lat Rhino & & & & 下甲介 & 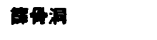 \\
\hline 20 & 54 & 女 & 街前埝斷 & なし & 14 & Denker+Killian法 & & & & 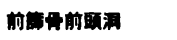 & 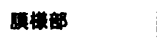 \\
\hline 21 & 49 & 男 & 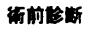 & なし & 123 & Lat Rhino & & & & 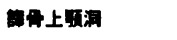 & \\
\hline 22 & 65 & 女 & 街後期断 & なし & 105 & Denkeri法 & & & & 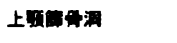 & \\
\hline 23 & 43 & 女 & 政前埌斷 & なし & 102 & Denker法 & & & & 厷蓸 & 鲜周不明 \\
\hline 24 & 48 & 其 & 分前此断 & なし & 72 & AER & & & & 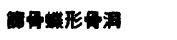 & 西累 \\
\hline 24 & 48 & 男 & 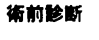 & なし & 72 & AER & & & & 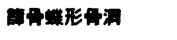 & 雨铜 \\
\hline 25 & 63 & 禺 & 沙前斯断 & なし & 53 & Lat Rhino & & & & 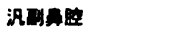 & 対四造展 \\
\hline 26 & 71 & 男 & 荋前店断 & あり & 91 & Lat Rhino & FESS & AER & & 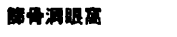 & 西祭 \\
\hline 26 & 71 & 另 & 䚘前歁 & あり & 91 & Lat Rhino & FESS & Killian法 & AER & 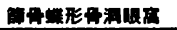 & 禹时 \\
\hline
\end{tabular}

AER: aggressive endoscopic resection, C-L法: Caldwell-Luc法, EN: endonasal (non-endoscopic)

FESS:functional endoscopic sinus surgery, Lat Rhino: lateral rhinotomy, SCFF: small canine fossa fenestration

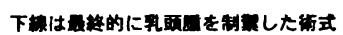




\section{結果}

追跡可能であった全鼻副鼻腔内反性乳頭腫26名

$(28$

側）の一覧表を表 2 に示す。

腫瘍の基部の発生部位（図 1 ）は上顎洞 8 例，上顎洞 篩骨洞 4 例，篩骨洞蝶形骨洞 4 例，篩骨洞前頭洞 3 例， 篩骨洞 2 例，中鼻甲介 2 例，下鼻甲介 1 例，沉副鼻腔 1 例, 沉副鼻腔および反対側進展 1 例（対側進展例として 扱った），基部が広基性で発生部位が同定不能であり基 部の記載が不十分なもの 2 例であった。

治療は全例手術療法であり，手術以外の治療法はなか った。初回に内視鏡のみ使用した群は 8 例，内視鏡以外 の術式は20例で, 乳頭腫を制禦できた最終術式（表 3 ） は内視鏡下広沉切除術 (aggressive endoscopic resection $)^{8)} 8$ 側, Denker 法 7 側, 外側鼻切開術 6 側, Denker 法 + Killian 法 3 側, FESS (functional endoscopic sinus surgery） 2 側，Caldwell-Luc 法，内視鏡下広汎切除術 +犬歯窩小孔 ${ }^{9101}$ 各 1 側である。但し本論文における FESS とは粘膜を保存する副鼻腔炎に対する標準的手術 で，内視鏡下広汎切除術 (aggressive endoscopic resection）とは副鼻腔炎に対する標準的手術に止まらず腫瘍 および基部の周辺粘膜と周辺骨を切除する術式を指す。

生検などを除いた手術回数は 1 回19側， 2 回 7 側, 3 回 2 側, 4 回 1 側であり,これらのうちの再発手術総計 10側14回の内訳は乳頭腫が 6 側10回, 術後性囊胞が 2 側 2 回, 副鼻腔炎または肉芽形成が 2 側 2 回であった。乳 頭腫再発例 6 側の前回手術は FESS 2 側, 外側鼻切開術 2 側, Denker 法 + Killian 法 1 側, 鼻内法 (内視鏡なし) 1 側であり, 内視鏡使用群は 8 側中 2 側 $(25.0 \%)$, 内 視鏡非使用群は20側中 4 側 $(20.0 \%)$ で再発したが再発

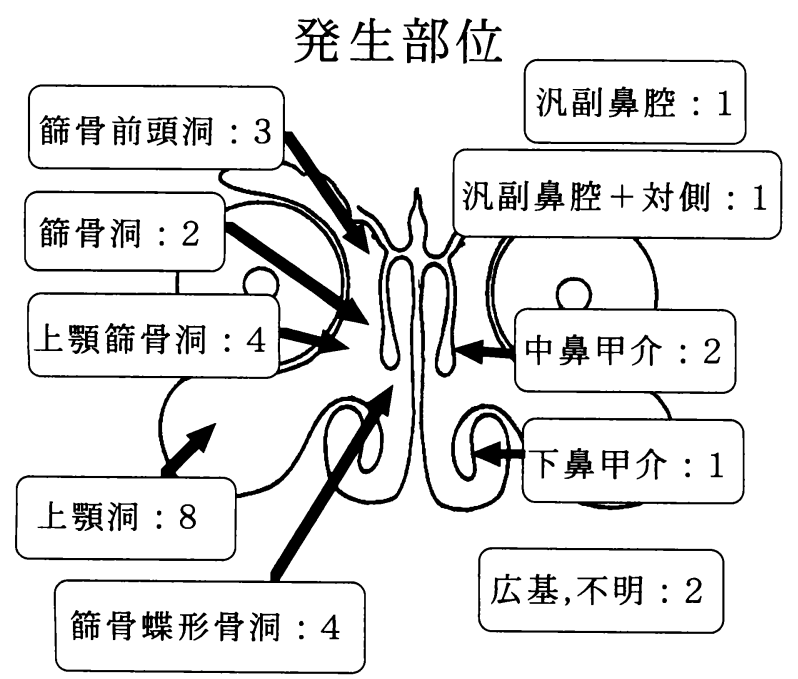

図 1
率に有意差はなかった（ $P>0.05 ） 。$

FESS 2 例の再発時手術は各々通常の FESSに周辺の 骨を含めた内視鏡下広沉切除術と内視鏡下広沉切除術 + small canine fossa fenestration（犬歯窩小孔）で，外側 鼻切開術 2 例は内視鏡下広沉切除術で, Denker 法 + Killian 法 1 例は Denker 法で, 鼻内法 1 例は外側鼻切開術 で最終的に制禦した。再発後の最終手術術式をまとめる と, 内視鏡下広沉切除術が 3 側, 外側鼻切開術が 1 側, Denker 法と内視鏡下広沉切除術 + 犬歯窩小孔が各 1 側 という結果であった。また再発までの期間（前回手術か ら再発時手術までの間隔) は平均 10.2 ヶ ( 7 〜 20ケ)

であった。

両側例 ${ }^{11,12,13)}$ は一般に稀で数\%程度の報告が多いが今 回の検討では 2 名 4 側 $(7.7 \%)$ において両側に各々独 立病変が認められ, 他の 1 名は前頭洞中隔を破壊して対 側の前頭洞に進展して両側化していた（図 $2 \mathrm{a}, \mathrm{b}) 。$

術前および術中迅速病理診断については乳頭腫が24 例, 炎症が 2 側, 術前病理検査なしが 2 例という結果で あった。乳頭腫の一部は肉眼的に炎症性ポリープと鑑別

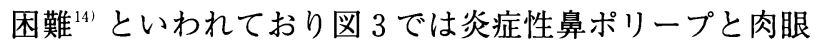
的に診断し術前病理標本を採取しなかった例である。

術式と出血量（表 4 ）を比較すると Denker 法 + Killian 法が $964 \pm 292 \mathrm{ml}$ ( 3 側), 外側鼻切開術が $884 \pm 263 \mathrm{ml}$ ( 7 側), Denker 法が $486 \pm 167 \mathrm{ml}$ ( 3 側), Caldwell-Luc 法が $232 \pm 186 \mathrm{ml}$ ( 2 側), 内視鏡下広沉切除術が $115 \pm$ $70 \mathrm{ml}$ ( 8 側 $),$ FESS が $104 \pm 114 \mathrm{ml}$ ( 3 側), 内 視 鏡下 広汎切除術 + 犬歯窩小孔が $40 \mathrm{ml}$ （1 側）であった。内 視鏡使用群の出血量は $106 \pm 88 \mathrm{ml}$, 内視鏡非使用群の出 血量は $670 \pm 353 \mathrm{ml}$ と明らかな有意差 $(P<0.0001)$ を 認めた。全経過を通じて悪性腫瘍の合併や観察期間中の 悪性化は認めなかった。

\section{考察}

鼻副鼻腔乳頭腫の再発性については1883年にHopmann ${ }^{15)}$ が, 悪性化については1889年にHellman ${ }^{16)}$ が最 初に報告して以来多くの報告がなされ，本疾患は依然と して取り扱いが困難と考えられている。さらに鼻副鼻腔

表 3

最終術式

\begin{tabular}{|c|c|}
\hline 内視鏡下広沉切除術（aggressive endoscopic resection） & 8 8例 \\
\hline Denker法 & 7側 \\
\hline 外側鼾切開術 & 6側 \\
\hline Denker法+ Killian法 & 3側 \\
\hline FESS (functional endoscopic sinus surgery) & 2側 \\
\hline Caldwell-Luc法 & 1 側 \\
\hline 内視鏡下広沉切除術+犬歯窩小孔 & 1 側 \\
\hline
\end{tabular}


領域の乳頭腫においては周辺組織への進展によって眼窩 内容物や脎硬膜の処理の問題が生じたり, 病理所見の多 椂性の問題, 例えば一部が悪性腫瘍, あるいは逆に一部 が炎症だったりという顕微鏡的病理所見の問題にも遭遇 する。鼻ポリープは日常的に遭遇する病変であるものの 一見乳頭腫との区別が困難?..1 な場合がある。図 3 のよ うに鼻鏡所見が乳頭腫に典型的所見でなくとも，ポリー プが不透明であったり，たいていは詳細に内視鏡で観察 すると内部の一部が分葉状・乳頭状，もしくは表面が凹 凸不整の部分を認めることが多いので漫然と鼻ポリープ として扱わず術前病理標本を採取したり，MRIで炎症 性病変と腫瘍性病変を鑑別"7 する心構えが成績向上につ ながる。それら肉眼的に鑑別が容易でない症例2.14 では 画像上副鼻腔炎と診断されて保存的手術が施行される可 能性があるため, Stankiewicz ら ${ }^{18)}$ は術前の内視鏡診断, 術中の生検の有用性を強調して抢り, 今回術前・術中病 理診断の有無による有意差はなかったものの術前・術中 病理診断なし群は 4 例中 2 例 $(50 \%)$ に再発を認め, 一 方術前・術中病理診断を行った上で手術した群は 24 例中

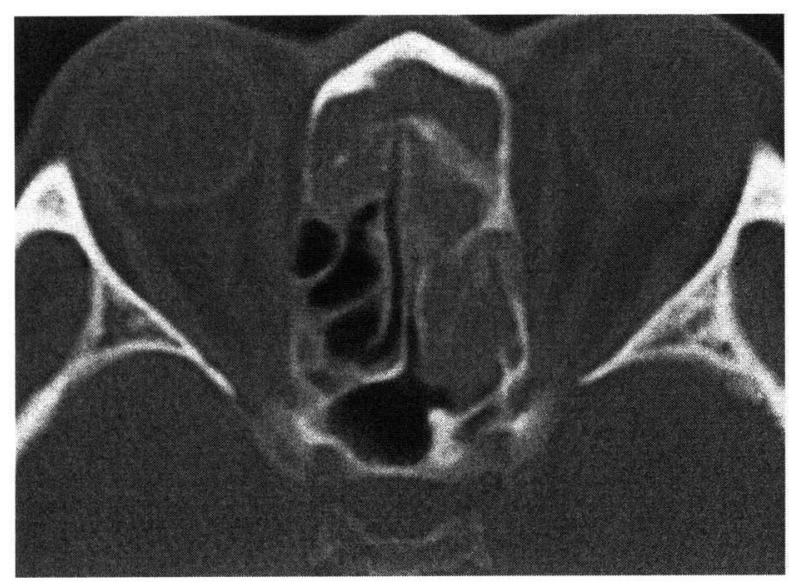

図 2 a 対側に進展した症例25の前頭洞軸位断 CT

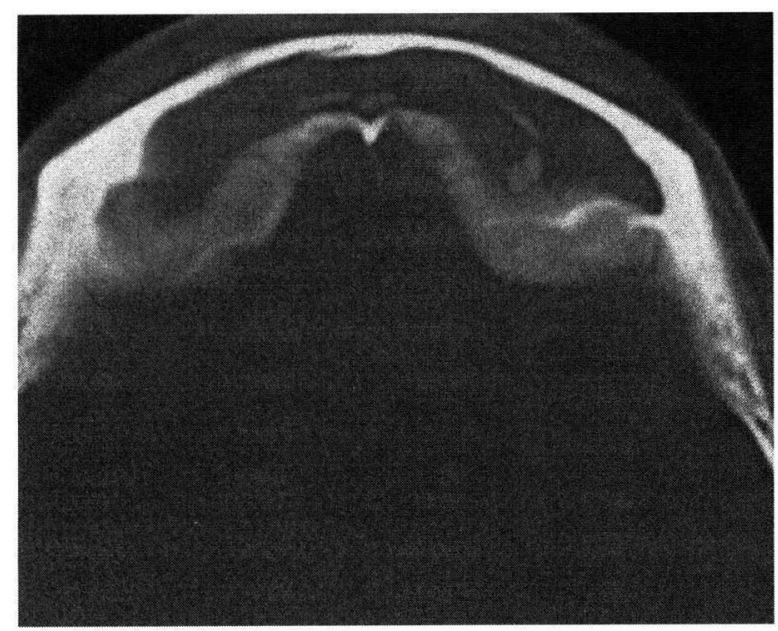

図 2 b 対側に進展した症例25の前節骨洞軸位断 CT
4 例（16.7\%）に再発した。また内視鏡使用群の 2 例の 再発例の術式は，いずれも内視鏡下広沉切除術ではなく FESSであった。術前に炎症という診断でFESSが施行 された場合 3 例（症例 $5,7,8$ ）中 2 例と高頻度 $(66.7 \%)$ に再発するという結果であったため，病理診 断の困難な本疾患では必ずしも全例術前に乳頭腫と病理 診断されるとは限らず病理学的限界が存在するととも に, 乳頭腫と病理診断された以上副鼻腔炎と同様の粘膜 保存術式は適応でないと判断した。

術前画像診断については，罹患洞およびその骨壁の韭 薄化や吸収像党 あるいは癌の合併の有無を確認玄るため の CT は必須であるが，骨病変がなく洞の混濁のみの軽 症例の場合炎症との鑑別が困難である。一方 MRI はや や腫瘍を過大評価する傾向があるものの炎症との鑑別に 適するため, 軟部組織内での腫瘍の進展範囲を評価する 目的において MRI ${ }^{4.17 .19 .201}$ が CT と相補的診断価値を持つ ことは疑いない。また本疾患では初発時に同時性悪性腫 瘍の合併（synchronous type）を念頭に置かねばならず， その目的でガリウムシンチグラフィー"をルーチンで行

表 4

術式と出血量

\begin{tabular}{|c|c|c|}
\hline Denker法+ Killian法 & $964 \pm 292 \mathrm{ml}$ & 3 側 \\
\hline 外側鼻切開術 & $884 \pm 263 \mathrm{ml}$ & 6 側 \\
\hline Denker 法 & $486 \pm 167 \mathrm{ml}$ & 7 側 \\
\hline Caldwell-Luc法 & $232 \pm 186 \mathrm{ml}$ & 2 側 \\
\hline 非内視鏡群 & $670 \pm 353 \mathrm{ml}$ & (18側) \\
\hline 内視鏡下広汎切除術 & $115 \pm 70 \mathrm{ml}$ & 8 側 \\
\hline FESS & $104 \pm 114 \mathrm{ml}$ & 3 側 \\
\hline 内視鏡下広汎切除術＋犬㐘洯小孔 & $40 \mathrm{ml}$ & 1 側 \\
\hline 内視鏡群 & $106 \pm 88 \mathrm{ml}$ & (12側) \\
\hline
\end{tabular}

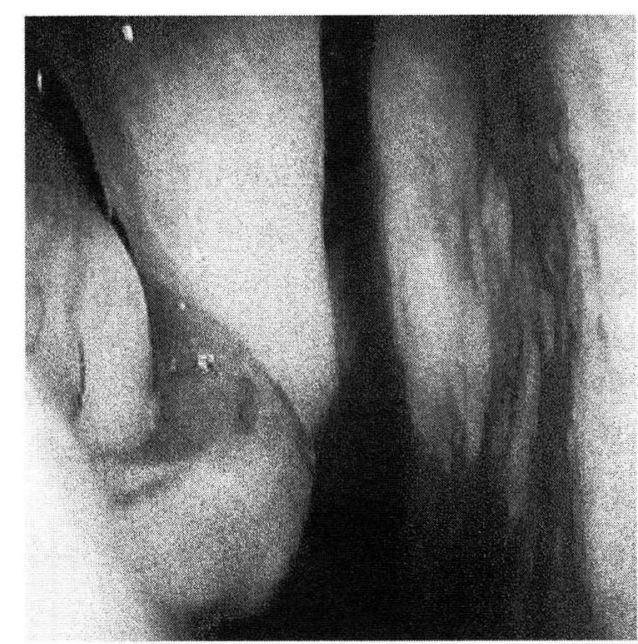

図 3 炎症性鼻ポリープと肉眼的に診断し術前 病理を採取しなかった症例 5 の右鼻内内 視鏡写真 
うことも推奖されている。以上より術前内視鏡・術前病 理・画像 (CT，MRI，Ga シンチグラフィー) による術 前診断を綿密に行った上で, 治療に臨むことは多くの論 文で繰り返し推奖されて扔り, 詳細な術前画像診断と病 理組織診打よび，術後数年にわたる内視鏡と画像による 経過観察が手術術式にも劣らず重要な鍵であることは論 を待たない。

再発率について文献的には最近ではほとんど内視鏡と 非内視鏡の両者を症例に応じ適宜選択した報告が多い が，これらの多くは内反性以外にも扁平上皮性乳頭腫を 含み観察期間が比較的短期でありまだ十分とは言えな い。内視鏡導入前の時代においては Skolnik ら ${ }^{211}$ の37\% （1966）から角田ら ${ }^{22)}$ の外側鼻切開術のみで8.3\% (1994) までの再発率が報告されてきたが, 内視鏡導入後, 木村 ら ${ }^{19)}$ は内視鏡と非内視鏡の両者で29\% (2001), 唐木ら ${ }^{23)}$ は両者で20\% (2001), Kaufman ら ${ }^{24)}$ は両者で18\% (2001), Schlosser ら $^{8)}$ 両者で19\% (2002), Klimek $ら^{5)}$ は両者で18\%（2001）, 吉川ら ${ }^{25)}$ は内視鏡群のみで 15\%（1999）, Han ら ${ }^{26)}$ は内視鏡群で10\%（非内視鏡群 で 8\%)（2002），であり，術式に関しては，特に侵襲と 再発率の間の相関の有無が盛んに議論されている ${ }^{3,6)}$ 状 態である。今回の検討では内視鏡使用群は 8 例中 2 例 $(25.0 \%)$, 内視鏡非使用群は 20 例中 4 例 $(20.0 \%)$ に再 発し再発率に両者間の有意差を認めなかった。今回内視 鏡下広沉切除術は外切開を加える術式と比べ, より軽症 例に選択されており，術後フォローアップの期間も異な り単純比較はできない。しかしながら，内視鏡下広沉切 除術は外切開を加える術式と比べ現在までのところ再発 率と出血量は明らかに少なく，手術侵襲に差があること は疑いがない。

また両側性は稀有とされ $\mathrm{Hozal}^{12)} 4 \%$ ，秋月 ${ }^{13)} 2$ から $4 \%$, Weissler ${ }^{27)} 9 \%$ と言われているがその多くは中隔 を超えての対側進展であり各々が独立的に発生すること はさらに稀である。当科では独立性 2 例, 対側進展 1 例, 合計 3 例 $(11.5 \%)$ と通常よりも多く認められた。これ は乳頭腫の多中心性発育の裏付けとなると同時に乳頭腫 には human papilloma virus 感染市に起因するものがあ ることを支持する結果と考えている。また両側病変であ っても安易に扱わず内視鏡所見と画像所見から腫瘍性病 変を鑑別する姿勢も重要である。

現在まで乳頭腫に対する様々な staging や進展範囲分 類が21, 25, 28,29) 提唱されているが，McCary ら ${ }^{30)}$ は内視鏡操 作の適応は基部の位置が同定でき，進展範囲が明瞭で, 全摘できることとしている。よって術前病理検查と画像 (CT のみならず MRI) ${ }^{4,17,19,20)}$ による術前の発生部位診断
を綿密に行った上で，まずほとんどの症例は内視鏡で手 術を開始し完全切除できる基部を探索することが条件 で，もし骨に腫瘍が付着していたらダイアモンドバーで 軽く腫瘍周辺骨を削除する ${ }^{311}$ か腫崵周辺骨とともにドリ

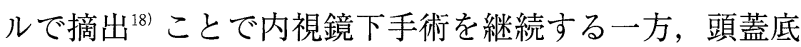
や鼻前頭管に基部を持つ場合内視鏡下手術と肉眼手術と を駆使したり，少なくとも肉眼手術の一部に内視鏡操作 や顕微鏡操作を併施する方針が推奨される。当科では両 手操作目的で鼻外手術 - 鼻中隔手術に通常顕微鏡併施を 行っているが顕微鏡下鼻内手術に慣れていないと視野の 確保に手間取る可能性もあり Waitz and Wigand ${ }^{6}$ (の術後 成績はマイクロデブリッダー導入前の時代であることを 考慮すると顕微鏡に関しては今後必須とは言い切れない かも知れない。Stankiewicz ら ${ }^{18)}$ は乳頭腫の場合副鼻腔 炎よりもつ权に1つ深部の洞まで開放し，上顎洞に関し ては Caldwell-Luc 法を施行する前にまず犬歯窩小孔か ら洞内を観察すると鼻内からは見落とされる病変の発見 につながることを示唆した。かつて Caldwell-Luc 法や Denker 法で行った上顎洞症例においては今後内視鏡下 + small canine fossa fenestration (大歯窩小孔) ${ }^{9,10)}$ によ ってまず洞内の観察をし，腫崵の基部は大きいか小さい か, 洞内は炎症か腫瘍か, 犬歯窩小孔からのアプローチ が可能かの判断をし必要ならば Caldwell-Luc 法あるい は Denker 法に切り替えることが推奨される。

鼻副鼻腔領域の内反性乳頭腫の悪性腫瘍の合併率は $0 \%{ }^{25}$ から $32 \%$ 监範囲で報告されているが，大規模な reviewに扔いては約10\% $\%^{322}$ から約 $13 \%{ }^{332}$ 程度である。 これは生命予後を左右する重大な因子であり，当科にお いて観察期間中の悪性化がなかったことについては主に 2 つの原因，つまり1つは分子生物学的な human papilloma virus サブタイプの相違"2, ひいては発癌過程にお ける転写因子活性や癌抑制遺伝子活性の相違が推察さ れ，もう1つは治療に際して形質転換した細胞や癌遺伝 子を完全摘出できたことが悪性化がなかったことに繋が ったかも知れない。

\section{ま と め}

当科で最近 10 年間に経験した鼻副鼻腔内反性乳頭腫症 例について検討した。

1. 再発率は28例中 6 例 $(21.4 \%)$ で悪性化は認めら れなかった。

2. 両側性は稀有とされるが当科では26名中 2 名 （7.7\%）と高頻度に認められた。

3. 術式と平均出血量を比較すると内視鏡使用群は $101 \mathrm{ml}$ ，内視鏡非使用群は $673 \mathrm{ml}$ と明らかな有意差 
$(P<0.0001)$ が認められた。

4. 再発後手術は内視鏡下広沉切除術 3 側, 内視鏡下 広沉切除術 + 犬歯窩小孔 1 側, 外側鼻切開術 1 側, Denker 法 1 側であり，再発例でも部位によっては必ず しも高侵襲手術なしで制禦可能と結論した。

この論文の要旨は第41回日本鼻科学会（2002年 9 月, 広島市）にてロ演した。

\section{参考文献}

1) Myers EN, Schramm VL, Barnes EL: Management of inverted papilloma of the nose and paranasal sinuses. Laryngoscope 91 : 2071-2084, 1981.

2 ) 熊谷正樹, 池田勝久, 高坂知節 : 頭頸部領域の乳頭 腫一その基礎と臨床一鼻・副鼻腔の乳頭腫. 耳喉頭 頸 $69: 835-840,1997$.

3 ) Myers EN, Petruzzelli GJ : Endoscopic sinus surgery for inverting papillomas. Laryngoscope 103 : 711, 1993.

4) Lawson W, Benger JL, Biller HF, et al: Inverted papilloma: An analysis of 87 cases. Laryngoscope 99 1117-1123, 1989.

5 ) Klimek T, Atai E, Glanz H, et al : Inverted papilloma of the nasal cavity and paranasal sinuses: clinical data, surgical strategy and recurrence rates. Acta Otolaryngol 120 : 267-272, 2000.

6 ) Waitz G, Wigand ME: Results of endoscopic sinus surgery for the treatment of inverted papillomas. Laryngoscope 102 : 917-922, 1992.

7 ) 川内秀之：鼻副鼻腔内反性乳頭腫の診断と治療.耳 鼻臨床 $96:$ 188-189, 2003.

8 ) Schlosser RJ, Mason JC, Gross CW : Aggressive endoscopic resection of inverted papilloma: an update. Otolaryngol Head Neck Surg 125: 49-53, 2001.

9 ）三澤逸人，鈴木 亨，中島 務，他：ESSに併施す る small canine fossa fenestration. 日耳鼻会報 120：補480, 1999.

10）柳 清, 今井 透, 飯村慈朗, 他 : 上顎洞に発生 する粘膜囊胞 (Mucosal cyst) に対する Minimum invasive surgery. Fenestration 法による Shaver system の使用. 耳展 $44: 278-283,2001$.

11) Tsue TT, Bailet JW, Makielski KH, et al : Bilateral sinonasal papillomas in aplastic maxillary sinuses. Am J Otolaryngol 18: 263-268, 1997.
12) Hozal SA, Freeman JL: Bilateral lateral rhinotomy for resection of bilateral inverted papilloma. Otolaryngol Head Neck Surg 114 : 103-105, 1996.

13）秋月浩光, 待木健司, 草刈 潤, 他：両側性鼻腔 inverted papilloma の 1 例.耳展 $41 ： 359-363$, 1998.

14) Stammberger $\mathrm{H}$ : Differential diagnosis. (ed) Stammberger $\mathrm{H}$ In Functional Endoscopic Sinus Surgery,B. C. Decker, Philadelphia, 262-267, 1991.

15) Hopmann CM : Die Papillaren Geschwulste der Nasenschleimhaut. Virchow Arch Path Anat 93 : 213-258, 1883.

16) Hellmann L: Papillom durum der Nasen-und-Stirnhölenschleimhaut. Übergang in Carcinom : Mit Rücksicht auf die Casuistic des harten Papilloms. Arch Otorhinolaryngol 6 : 171-192, 1897.

17）湯本英二, 兵頭政光, 比野平恭之, 他：鼻副鼻腔乳 頭腫 6 例の治療経験一保存的手術の役割一. 耳鼻臨 床 $88 ； 733-738,1995$.

18) Stankiewicz JA, Girgis SJ : Endoscopic surgical treatment of nasal and paranasal sinus inverted papilloma. Otolaryngol Head Neck Surg 109: 988995, 1993.

19）木村哲郎, 坂倉康夫, 間島雄一, 他 : 鼻副鼻腔乳頭 腫症例の検討. 耳鼻臨床 $94: 795-799,2001$.

20) Savy L, Lloyd G, Howard D, et al : Optimum imaging for inverted papilloma. J Laryngol Otol 114 : 891-893, 2000

21) Skolnik EM, Loewy A, Friedman JE: Inverted papilloma of the nasal cavity. Arch Otolaryngol 84, 8389, 1966.

22）角田玲子, 竹生田勝次, 西鴧 渡, 他：鼻 - 副鼻腔 の inverted papillomaの臨床的検討. 日耳鼻会報 97 : 912-918, 1994.

23）唐木將行, 小林隆一, 森望, 他：鼻副鼻腔乳頭 腫の検討. 日鼻誌 $40: 6-11,2001$.

24) Kaufman MR, Brandwein MS, Lawson W: Sinonasal papillomas: clinicopathologic review of 40 patients with inverted and oncocytic schneiderian papillomas. Laryngoscope 112 : 1372-1377, 2002.

25）吉川 衛, 森山 寛, 柳 清, 他：鼻副鼻腔乳頭 腫に対する内視鏡下鼻内手術の適応と限界. 耳展 40:411-415, 1997.

26) Han JK, Smith TL, Smith MM, et al : An evolution in the management of sinonasal inverting papilloma. 
Laryngoscope 111 : 1395-1400, 2001.

27) Weissler MC, Montgomery WW, Joseph MP, et al: Inverted papilloma. Ann Otol Rhinol Laryngol 95, 215-221, 1986.

28) Krouse JH : Development of a staging system for inverted papilloma. Laryngoscope 110, 965-968, 2000.

29）池田勝久，鈴木秀明，高坂知節，他：鼻副鼻腔内向 型乳頭腫に対する内視鏡下鼻内手術. 耳喉頭頸 $67: 765^{-768,} 1995$.

30) McCary WS, Gross CW, Reibel JF, et al : Preliminary report: Endoscopic versus external surgery in the management of inverted papilloma. Laryngoscope 104 : 415-419, 1994.

31) Kennedy DW : The expanding role of endoscopic sinus surgery -Tumors, skull base defects and orbital surgery- 日鼻誌 $37 ： 5-10,1998$.

32) Batsakis JG, Suarez P : Schneiderian papillomas and carcinomas: a review. Adv Anat Pathol 8: 53-64, 2001.

33) Hyams VJ : Papillomas of the nasal cavity and paranasal sinuses : a clinicopathological study of 315 cases. Ann Otol Rhinol Laryngol 80 : 192-206, 1971.

(2003年 5 月 2 日受稿, 2003 年 6 月 23 日受理) 別刷請求先 : 三澤 逸人

干466-8550 名古屋市昭和区鶴舞町65

名古屋大学大学院医学系研究科頭頸部 · 感覚器外科学講座耳鼻咽喉科学教室

Tel : 052-744-2323 FAX : 052-744-2325 